\title{
Hepatic hydatid disease requiring urgent treatment during pregnancy
}

\author{
Hamilelik sırasında acil tedavi gerektiren karaciğer kist hidatiği
}

\author{
Candaş ERÇETIN, İlgin ÖZDEN, Cem İYİBOZKURT, Koray GÜVEN, Kürşat SERİN, \\ Orhan BILLGE, Yaman TEKANT, Aydın ALPER, Ali EMRE
}

\section{BACKGROUND}

Pregnant women may experience an acute presentation of hepatic hydatid disease. The available literature is limited to case reports.

\section{METHODS}

The charts of 7 patients who underwent urgent treatment for hepatic hydatid disease during pregnancy between 1992 and 2010 were reviewed.

\section{RESULTS}

The median patient age was 27 (range 23-39) years and median gestational age was 18 (range 13-24) weeks. The symptoms were severe abdominal pain (4), vomiting (2), jaundice (2), pruritus (2) and severe dyspepsia (1); in the asymptomatic patient, a closed intraperitoneal rupture had been detected during gynecologic ultrasonography. Surgical drainage of the cysts was performed in all cases. The two patients with frank biliary rupture underwent choledochoduodenostomy or Roux-Y hepaticojejunostomy. Four patients required postoperative tocolysis. Albendazole was not used. All mothers gave birth to healthy babies at term. The patients were followed for a median of 9 (range 4-19) years. Two patients developed recurrences at 2 and 7 years; these were treated with surgical drainage and albendazole.

\section{CONCLUSION}

This entity entails the responsibility of two human beings. Although it imposes limitations on the routine diagnostic and therapeutic options due to risk of premature labor or teratogenicity, acceptable results can be obtained in collaboration with the department of obstetrics and gynecology.

Key Words: Albendazole; complication; hepatic hydatidosis; liver; pregnancy; T-drainage.

\section{AMAÇ}

Karaciğer kist hidatiği hamile kadınlarda, akut gelişen tablolarla ortaya çıkabilir. Literatürdeki deneyim, olgu sunumları ile sinırlıdır.

\section{GEREÇ VE YÖNTEM}

1992-2010 y1lları arasında, hamilelik sirasında acil tedavi uygulanması gereken karaciğer kist hidatikli yedi hastanın kayıtları değerlendirildi.

\section{BULGULAR}

Ortanca (sınırlar) hasta yaşı 27 (23-39) y1l, ortanca (sınırlar) gestasyon yaş1 18 (13-24) haftaydı. Semptomlar şiddetli karın ağrısı (4), kusma (2), sarılık (2), kaşıntı (2) ve ağır dispepsiydi (1); semptomsuz hastada (1), jinekolojik ultrasonografi sirasinda rastlantısal olarak, kapalı intraperitoneal yırtılma gözlendi. Bütün kistlere cerrahi drenaj uygulandı. Safra yollarına boşalma gözlenen iki hastada koledokoduodenostomi ve Roux-Y hepatikojejunostomi uyguland. Dört hastada ameliyat sonrası tokoliz gerekti. Albendazol kullanılmadı. Annelerin hepsi, miadında sağliklı bebekler doğurdular. Hastalar ortanca (sınırlar) 9 (419) yıl izlendi. İki hastada ikinci ve yedinci yıllarda nüksler gelişti, bunlar cerrahi drenaj ve albendazol ile tedavi edildi.

\section{SONUÇ}

Hamilelik sırasında acil tedavi gerektiren kist hidatik, aynı anda iki insanın sorumluluğunun alınmasını zorunlu kılar. Prematür doğum ve teratojenite riskleri nedeniyle rutin tanı ve tedavi yöntemlerinin kullanımı sınırlansa da, kadın hastalıkları ve doğum kliniği ile işbirliğine gidilerek, kabul edilebilir sonuçlar elde edilebilmektedir.

Anahtar Sözcükler: Albendazol; komplikasyon; hepatik kist hidatik; karaciğer; gebelik; T-drenaj. 
Pregnant women may experience an acute presentation of hepatic hydatid disease with pain, ${ }^{[1-4]}$ vomiting, ${ }^{[5]}$ pruritus, ${ }^{[1,6]}$ jaundice, ${ }^{[5]}$ cholangitis ${ }^{[7]}$ and emergence of a mass. ${ }^{[8]}$ The incidence of this rare condition is unknown. Although, a figure of 1 in 20,000-30,000 pregnancies is quoted in numerous papers, the original 1982 report from Libya (an endemic region) by Rahman et al. ${ }^{[9]}$ includes only obstetric and gynecological presentations of hydatid disease; all 14 patients had pelvic hydatid disease, while 4 had a history of hepatic cysts. Authors from the Regional Hospital of Temuco, Chile (a regional reference center in an endemic region), reported an estimated figure of $0.07 \%$ for abdominal (mostly hepatic) echinococcosis during pregnancy; their series included patients diagnosed by routine prenatal abdominal ultrasonography. ${ }^{[10]}$ Consequently, the reported experience on urgent treatment of hepatic disease is limited to case reports on surgery alone ${ }^{[1,2,7,8,11]}$ surgery and antihelminthic chemothera$\mathrm{py}_{,}{ }^{[3,5]}$ antihelminthic chemotherapy alone ${ }^{[12]}$ and percutaneous treatment. ${ }^{[13]}$

In contrast with the situation in nonpregnant patients, this entity entails the responsibility of two human beings and unfortunately imposes limitations on the routine diagnostic and therapeutic options due to risks of premature labor or teratogenicity: these include laparotomy, computed tomography (CT), endoscopic retrograde cholangiopancreatography (ERCP) and albendazole.

In this paper, the experience of 7 hepatic hydatid disease patients who required urgent treatment during pregnancy is reported and recommendations on how successful maternal and fetal outcome can be achieved are made.

\section{MATERIALS AND METHODS}

The charts of 7 patients treated for an acute presentation of hepatic hydatid disease during pregnancy were reviewed to identify the presenting symptoms, treatment methods and results.

\section{RESULTS}

Between 1992 and 2010, 7 pregnant patients were treated for hepatic hydatid disease at the Hepatopancreatobiliary Surgery Unit of the Istanbul Faculty of Medicine, Istanbul University. The median patient age was 27 (range 23-39) years and median gestational age was 18 (range 13-24) weeks. Only one patient had a past history of hydatidosis; she had undergone surgery for a brain lesion 13 years ago but was not under routine follow up. The presenting symptoms are summarized in Table 1. In the asymptomatic patient, the hepatic cyst was detected during gynecologic ultrasonography and a magnetic resonance imaging (MRI) examination was performed. Radiologic demonstration of a closed
Table 1. The presenting symptoms of the patients

\begin{tabular}{ll}
\hline Severe abdominal pain & 4 \\
Vomiting & 2 \\
Jaundice & 2 \\
Pruritus & 2 \\
Severe dyspepsia & 1 \\
None* & 1 \\
\hline & The hepatic cyst had been detected during gynecologic \\
ultrasonography and a magnetic resonance imaging (MRI) examination \\
was performed. Radiologic demonstration of a closed rupture into the \\
peritoneal cavity (Fig. 1) prompted referral to our center.
\end{tabular}

rupture into the peritoneal cavity (Fig. 1) prompted referral to our center. The diagnosis was made by ultrasonography (7 patients) and MRI (6 patients). All lesions were located in the right hemiliver. Six patients had single cysts and one patient had two cysts. Median lesion size was $122 \mathrm{~mm}$ (range 70-170 mm).

All patients were treated in collaboration with the department of obstetrics and gynecology. None of the referred patients were considered suitable for conservative follow up and surgical drainage of the cysts was performed in all cases. Two patients had frank rupture into the biliary tree (Fig. 2); they underwent common bile duct exploration followed by choledochoduodenostomy or Roux-Y hepaticojejunostomy. Two patients had major cystobiliary communications which were sutured primarily; there was no hydatid material in the common bile duct; T-tube drainage and Y-tube (with additional side holes) drainage (due to low union of the right posterior sectional hepatic duct to the distal common bile duct) were used to keep the biliary tree pressure low and prevent a biliocystic fistula.

Four patients required postoperative tocolysis. One patient had a biliocystic fistula. One patient had an unexplained episode of hepatitis which resolved spontaneously; no etiology could be determined. The T-tube

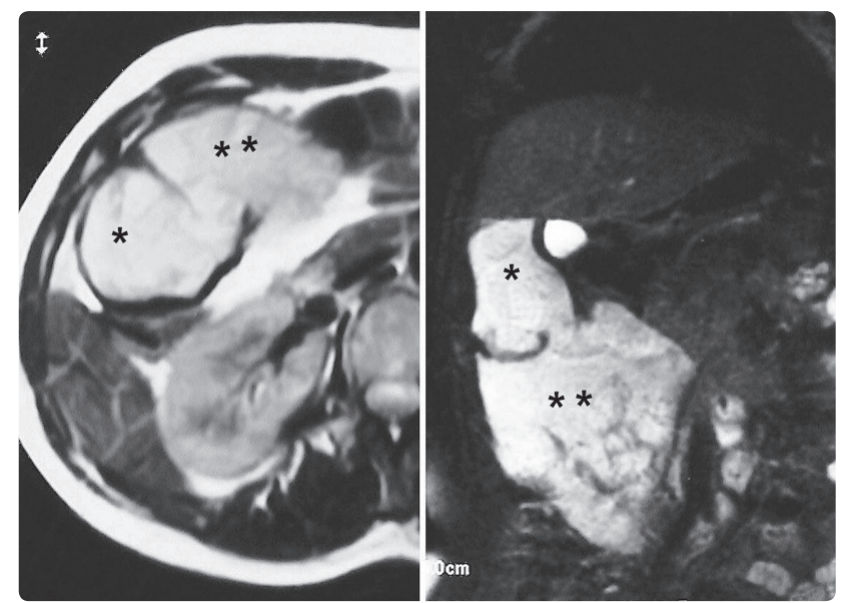

Fig. 1. Hepatic hydatid cyst (asteriks) with spontaneous closed rupture into the abdominal cavity (double asteriks). 


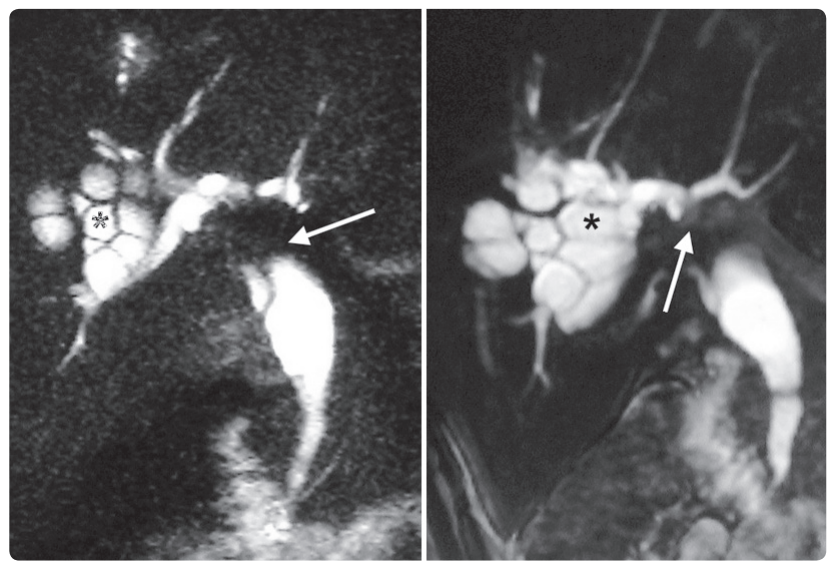

Fig. 2. Multiloculated hydatid cyst (asterisk) with frank rupture into the biliary tree; cyst material obstructing the hilar confluence (arrow).

and the Y-tube were left open until delivery. Albendazole was not used due to the risk of teratogenicity. All mothers gave birth to healthy babies at term.

The patients were followed for a median of 9 (range 4-19) years. Two patients developed recurrences at 2 and 7 years; these were treated with surgical drainage and albendazole.

\section{DISCUSSION}

Although definite data are not available, conservative follow up of hepatic hydatid cysts diagnosed incidentally during pregnancy appeared to be the best option. ${ }^{[14]}$ Cysts with acute presentation, however, require urgent treatment with judicious use of diagnostic and therapeutic options with regard to the risks of premature labor or teratogenicity.

The diagnosis of hepatic hydatidosis can be made reliably by ultrasonography. Lung radiography and computed tomography, which are useful in evaluating the extent of the disease (e.g. deep intrahepatic cysts in 'blind spots' of ultrasonography, other intraabdominal cysts which may be missed during laparotomy, asymptomatic lung cysts which may nevertheless require urgent treatment due to the risk of severe complications such as intrabronchial rupture) should be replaced by MRI. MRI is also useful in demonstrating significant biliary involvement which was present in 4 of the 7 patients in this series.

Mebendazole and albendazole are useful in the primary treatment of hepatic hydatidosis as well as prevention of postoperative recurrences in nonpregnant patients. ${ }^{[15]}$ However, their use cannot be justified in pregnant women with acute complications because these drugs have been shown to be teratogenic in experimental studies. ${ }^{[15]}$ We avoided the use of albendazole in all of our patients and experienced recurrences in 2 of 7 patients. Although the number of patients is too small for definite statements, we have to accept the pos- sibility that our approach may have had a role because we routinely prescribe albendazole perioperatively to all other patients. In every case, the attending physician discussed this issue with the patient and her family. All patients and families followed our recommendation to withhold albendazole in view of the unpredictable fetal risks and the generally accepted but imprecisely defined benefits in the prevention of recurrences.

ERCP is an effective method in the treatment of biliary complications of hepatic hydatid disease. ${ }^{[16,17]}$ Although "nonradiation ERCP" in pregnant patients has been reported, ${ }^{[18,19]}$ the experience is limited. Complete ductal clearance cannot be ascertained without a choledochoscopy, which may not be technically possible in every case. ${ }^{[18]}$ Also, the inevitable increase of intra-abdominal pressure, especially during long procedures, may be detrimental to fetal circulation.

Percutaneous treatment is a well-established procedure in uncomplicated hepatic cysts. ${ }^{[20,21]}$ Its role in pregnant patients with an acute presentation is limited to large cysts, which cause significant pain and vomiting. ${ }^{[13]}$ However, it is worth keeping in mind that such cysts have a high possibility of biliary communication which compromise the treatment and require additional procedures. In addition, although proponents argue that the risk of anaphylaxis during percutaneous treatment is similar to that of surgery, ${ }^{[13]}$ there is no definitive data and the management of anaphylaxis is obviously less complicated in an intubated patient under general anesthesia.

Our department prefers to conduct open surgery with prompt evacuation of the cysts, treatment of biliary involvement and management of the cavity. ${ }^{[22,23]}$ Leaving the T-tube and the Y-tube open until delivery may be criticized from a quality of life point of view. These patients had normal size bile ducts and large intrahepatic cystobiliary communications. The tubes successfully prevented bile leakage to the cyst from the repaired areas.

It is generally accepted that the fetal wastage rate due to elective surgery during pregnancy is lowest in the second trimester. ${ }^{[24,25]}$ Although acute presentation of the patients in this series did not allow elective treatment, it was a fortunate coincidence that all were in the second trimester. The vital role of close collaboration with the obstetrics and gynecology department can not be overemphasized. All patients were monitored closely by our colleagues. Although the pelvic region was not manipulated, 4 of the 7 mothers required tocolysis. All mothers gave birth to healthy babies at term.

In conclusion, hepatic hydatid disease requiring urgent treatment during pregnancy entails the responsibility of two human beings. Although it imposes 
limitations on the routine diagnostic and therapeutic options due to risk of premature labor or teratogenicity, acceptable results can be obtained in collaboration with the department of obstetrics and gynecology.

Conflict-of-interest issues regarding the authorship or article: None declared.

\section{REFERENCES}

1. Crow JP, Larry M, Vento EG, Prinz RA. Echinococcal disease of the liver in pregnancy. HPB Surg 1990;2:115-9.

2. Haxhimolla HZ, Crowe P. Hydatid disease of the liver in pregnancy. ANZ J Surg 2001;71:692-3.

3. Montes H, Soetkino R, Carr-Locke DL. Hydatid disease in pregnancy. Am J Gastroenterol 2002;97:1553-5.

4. Poiat C, Sivaci R, Baki E, Kosar MN, Yiimaz S, Arikan Y. Recurrent hepatic hydatid cyst in a pregnant woman. Med Sci Monit 2007;13:CS27-9.

5. Golaszewski T, Susani M, Golaszewski S, Sliutz G, Bischof G, Auer H. A large hydatid cyst of the liver in pregnancy. Arch Gynecol Obstet 1995;256:43-7.

6. Kain KC, Keystone JS. Recurrent hydatid disease during pregnancy. Am J Obstet Gynecol 1988;159:1216-7.

7. Blöchle C, Lloyd DM, Izbicki JR, Schröder S, Brölsch CE. Right-sided hemihepatectomy in echinococcosis of the liver in pregnancy. [Article in German] Chirurg 1993;64:580-3. [Abstract]

8. Can D, Oztekin O, Oztekin O, Tinar S, Sanci M. Hepatic and splenic hydatid cyst during pregnancy: a case report. Arch Gynecol Obstet 2003;268:239-40.

9. Rahman MS, Rahman J, Lysikiewicz A. Obstetric and gynaecological presentations of hydatid disease. Br J Obstet Gynaecol 1982;89:665-70.

10. Manterola C, Espinoza R, Muñoz S, Vial M, Bustos L, Losada $\mathrm{H}$, et al. Abdominal echinococcosis during pregnancy: clinical aspects and management of a series of cases in Chile. Trop Doct 2004;34:171-3.

11. Sahin E, Nayki U, Sadik S, Oztekin O, Nayki C, Kizilyar A, Gungor O. Abdominal and pelvic hydatid disease during pregnancy. Arch Gynecol Obstet 2005;273:58-9.

12. van Vliet W, Scheele F, Sibinga-Mulder L, Dekker GA. Echinococcosis of the liver during pregnancy. Int J Gynaecol Obstet 1995;49:323-4.
13. Ustünsöz B, Alemdaroğlu A, Bulakbaşi N, Uzar AI, Duru NK. Percutaneous treatment of hepatic hydatid cyst in pregnancy. Arch Gynecol Obstet 1999;262:181-4.

14. Rodrigues G, Seetharam P. Management of hydatid disease (echinococcosis) in pregnancy. Obstet Gynecol Surv 2008;63:116-23.

15. Guidelines for treatment of cystic and alveolar echinococcosis in humans. WHO Informal Working Group on Echinococcosis. Bull World Health Organ 1996;74:231-42.

16. Cicek B, Parlak E, Disibeyaz S, Oguz D, Cengiz C, Sahin B. Endoscopic therapy of hepatic hydatid cyst disease in preoperative and postoperative settings. Dig Dis Sci 2007;52:9315.

17. Tekant Y, Bilge O, Acarli K, Alper A, Emre A, Arioğul O. Endoscopic sphincterotomy in the treatment of postoperative biliary fistulas of hepatic hydatid disease. Surg Endosc 1996;10:909-11.

18. Shelton J, Linder JD, Rivera-Alsina ME, Tarnasky PR. Commitment, confirmation, and clearance: new techniques for nonradiation ERCP during pregnancy (with videos). Gastrointest Endosc 2008;67:364-8.

19. Akcakaya A, Ozkan OV, Okan I, Kocaman O, Sahin M. Endoscopic retrograde cholangiopancreatography during pregnancy without radiation. World J Gastroenterol 2009;15:3649-52.

20. Akhan O, Ozmen MN. Percutaneous treatment of liver hydatid cysts. Eur J Radiol 1999;32:76-85.

21. Giorgio A, de Stefano G, Esposito V, Liorre G, Di Sarno A, Giorgio V, et al. Long-term results of percutaneous treatment of hydatid liver cysts: a single center 17 years experience. Infection 2008;36:256-61.

22. Arioğul O, Emre A, Alper A, Uras A. Introflexion as a method of surgical treatment for hydatid disease. Surg Gynecol Obstet 1989;169:356-8.

23. Alper A, Ariogul O, Emre A, Uras A, Okten A. Choledochoduodenostomy for intrabiliary rupture of hydatid cysts of liver. Br J Surg 1987;74:243-5.

24. Jabbour N, Brenner M, Gagandeep S, Lin A, Genyk Y, Selby $\mathrm{R}$, et al. Major hepatobiliary surgery during pregnancy: safety and timing. Am Surg 2005;71:354-8.

25. Giuntoli RL 2nd, Vang RS, Bristow RE. Evaluation and management of adnexal masses during pregnancy. Clin Obstet Gynecol 2006;49:492-505. 